From the State Veterinary Institute for Virus Research, Lindholm, Kalvehave, and Danish Bacon and Meat Council, Veterinary Division, Axelborg, Copenhagen, Denmark.

\title{
Efficacy of an Inactivated Porcine Parvovirus (PPV) Vaccine under Field Conditions
}

\author{
By K. J. Sørensen, P. Madsen and J. C. Lei.
}

\begin{abstract}
Sørensen, K. J., P. Madsen and J. C. Lei: Efficacy of an inactivated porcine parvovirus (PPV) vaccine under field conditions. Acta vet. scand. 1988, 29, 295-302. Dose response experiments were carried out by vaccinating groups of seronegative gilts (7 months of age) and groups of gilts with residual maternal serum antibodies to PPV (5 months of age). PPV vaccines containing different amounts of inactivated virions were used. Vaccinations were carried out twice with 3 weeks intervals. It was demonstrated, that a single vaccination even with a vaccine with low antigen content elicited an antibody response to PPV in seronegative gilts. The titer values increased after the 2 nd vaccination.

When the gilts had residual maternal serum antibodies at the time of vaccination the antibody response was generally lower. In some animals the titer values decreased after the 1st vaccination, but except for 2 gilts vaccinated with vaccines with a low antigen content an increase of titer values followed after the 2 nd vaccination. During a field trial performed in a herd with enzootic PPV infection all the gilts were vaccinated with PPV vaccine before mating. Blood samples were examined for $\mathrm{HI}$ antibodies before and after vaccination and at weaning time of each of the resulting 5 litters. In total 24 batches of gilts comprising 326 animals mated during a 2 year period were examined. It was demonstrated, that the applied vaccine preparations used under field conditions gave a relatively high and long lasting antibody response, even when the gilts were vaccinated as early as at about 5 months of age.
\end{abstract}

dose response; field trial.

\section{Introduction}

Several vaccines against porcine parvovirus (PPV) infection have been tested under experimental conditions (Fujisaki et al. 1978 a, b, Mengeling et al. 1979, 1981, Paul \& Mengeling 1980, Sørensen \& Askaa 1981, Wrathal et al. 1984, Joo et al. 1984, Plana et al. 1984 and Edward et al. 1986). Usually, seronegative gilts have been employed. However, when vaccination is performed under field conditions the animals often have residual maternal serum antibodies, which may interfere with the antibody response (Paul \& Mengeling 1986).

In the present paper the antibody response following vaccination of groups of seronegative gilts and groups of gilts with residual maternal serum antibodies has been investigated. In addition, the antibody response of different amounts of antigen in the vaccine was studied. Finally, data are presented on the long-term serostatus of breeding animals in a herd with vaccination of all gilts before mating. 


\begin{abstract}
Materials and methods
Vaccines

PPV vaccine was prepared as previously described (Lei et al. 1980). Unless otherwise indicated the preparations were adjusted on the basis of quantitative ultracentrifugation to contain $0.50 \mu \mathrm{g}$ of inactivated virions per $\mathrm{ml}$ of vaccine.
\end{abstract}

\section{Dose response experiments}

The PPV vaccine preparations applied contained the following amounts of inactivated virions: Vaccine a: $0.74 \mu \mathrm{g}$, vaccine b: 0.19 $\mu \mathrm{g}$, vaccine c: $0.05 \mu \mathrm{g}$ and vaccine $\mathrm{d}: 0.01 \mu \mathrm{g}$ per $\mathrm{ml}$.

1) On a farm with PPV seronegative gilts 4 groups each consisting of 7 to 8 gilts about 7 months of age were vaccinated each with one of the 4 vaccine preparations. Vaccination was carried out twice at an interval of 3 weeks by subcutaneous injection of $2 \mathrm{ml}$ and $1 \mathrm{ml}$ of vaccine, respectively.

2) On another farm with enzootic PPV infection 4 groups, each consisting of 3 to 5 gilts 5 months of age and with residual maternal serum antibodies to PPV, were vaccinated as mentioned above.

Blood samples for examination for hemagglutination inhibiting (HI) antibodies were collected at the time of 1 st and 2 nd vaccination and 3 weeks after the 2 nd vaccination.

\section{Vaccination trial}

A vaccination trial with PPV vaccine was performed in a herd with enzootic PPV infection. All the gilts (mostly pure Danish Landrace) were vaccinated at 5-7 months of age. Vaccination was carried out before mating. Two subcutaneous injections with 2 $\mathrm{ml}$ and $1 \mathrm{ml}$ of vaccine, respectively, were given at a 3 weeks interval. Blood samples were collected for $\mathrm{HI}$ antibody testing at the time of the 1 st and the 2 nd vaccination, 3 weeks after the 2 nd vaccination and at weaning time of each of the resulting 5 litters. Twenty four batches of gilts comprising a total of 326 animals, mated during a two year period, were tested.

Before the trial was initiated all the breeding animals of the herd were tested for HI antibodies to PPV. All animals with HI titers $>256$ were considered to have seroconverted as a result of PPV infection.

\section{Revaccination experiment}

Two groups each consisting of 6 sows (vaccinated as gilts) with relatively low HI-antibody titers to PPV were revaccinated with 1 $\mathrm{ml}$ and $2 \mathrm{ml}$ of PPV vaccine, respectively, before or at the time of weaning of their 5th or 6th litter. Blood samples were taken at the time of revaccination and 3 weeks later.

\section{Laboratory test}

Examination of sera for $\mathrm{HI}$-antibodies to PPV was performed as described previously (Sørensen \& Askaa 1981).

\section{Results}

Dose response experiments

1) All gilts except one in the seronegative groups mounted an antibody response after the 1st vaccination followed by an increase of titer values after the 2nd vaccination. Even vaccine $d$ elicited HI-titers ranging from 16 to 128 after the 1 st vaccination (Fig. 1).

2) When maternal serum antibodies were present, the antibody response after vaccination was generally lower (Fig. 2). The vaccines $\mathrm{a}$ and $\mathrm{b}$ elicited comparable antibody responses, whereas the vaccines $\mathrm{c}$ and $\mathrm{d}$ gave weaker responses. In some animals the titer values decreased after the 1 st vaccination even with vaccine a, and did not increase until after the 2 nd vaccination. In 1 animal vaccinated with vaccine $\mathrm{c}$ the titer value remained the same (HI titer 16 ) after both vac- 



Figure 1. Dose response experiment carried out by vaccinating groups of seronegative gilts using vaccines containing decreasing amounts of inactivated virions: a) $0.74 \mu \mathrm{g}, \mathrm{b}) 0.19 \mu \mathrm{g}, \mathrm{c}) 0.05 \mu \mathrm{g}$ and d) $0.01 \mu \mathrm{g}$ per $\mathrm{ml}$. The parentheses indicates mean antibody titer values.
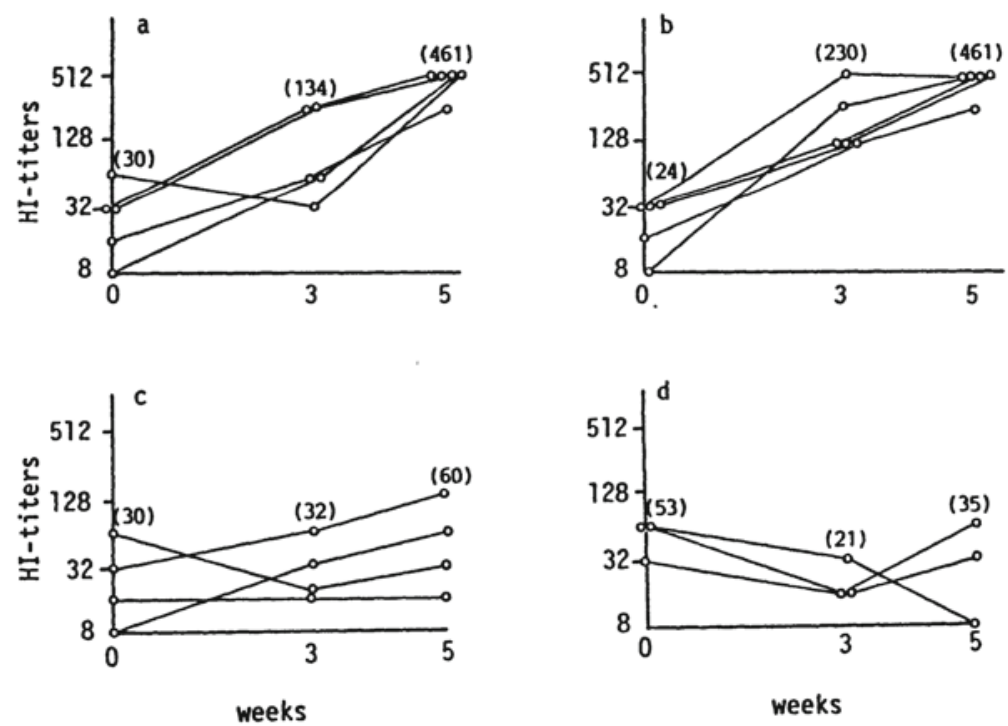

Figure 2. Dose response experiment carried out by vaccinating groups of gilts with maternal serum antibodies using decreasing amounts of inactivated virions. Explanations as in Fig. 1. 
cinations. In another animal vaccinated with vaccine $d$ the titer value decreased from 64 to 32 after the 1st vaccination and from 32 to 8 after the 2 nd vaccination.

\section{Vaccination trial}

At the start of the vaccination trial only few of the breeding animals had experienced infection with PPV as determined by seroconversion to PPV before the age of 9 months. On the other hand almost all breeding animals over 12 months of age had seroconverted to PPV (Table 1).

Table 1. The prevalence of PPV-seroconverted breeding animals before the start of a vaccination trial in a herd with enzootic PPV infection.

\begin{tabular}{lcrr}
\hline \multirow{2}{*}{$\begin{array}{l}\text { Age } \\
\text { (months) }\end{array}$} & $\begin{array}{c}\text { Total number } \\
\text { of animals }\end{array}$ & \multicolumn{2}{c}{$\begin{array}{c}\text { Seroconverted } \\
\text { animals }\end{array}$} \\
\cline { 3 - 4 } & & Number & $\%$ \\
\hline $6-7$ & 30 & 2 & 7 \\
$7-8$ & 16 & 2 & 13 \\
$8-9$ & 4 & 0 & 0 \\
$9-10$ & 37 & 12 & 32 \\
$10-11$ & 12 & 9 & 75 \\
$11-12$ & 11 & 8 & 73 \\
$>12$ & 456 & 447 & 98 \\
\hline
\end{tabular}

During the first 4 months of the trial the percentage of gilts, which had seroconverted to PPV at the time of vaccination decreased further, so that after 4 months no gilts (except for 1 in a batch comprising 11 gilts) had seroconverted to PPV at the time of vaccination. After 18 months, however, a considerable number of gilts, had seroconverted to PPV at the time of vaccination (Fig. 3). Considering the whole period of the vaccination trial most of the gilts only had residual maternal serum antibodies to PPV at the time of the 1st vaccination with a peak of the distribution curve at HI-titer value 16 (Fig. 4). After the 1st vaccination this peak of the distribution curve moved to HI-titer

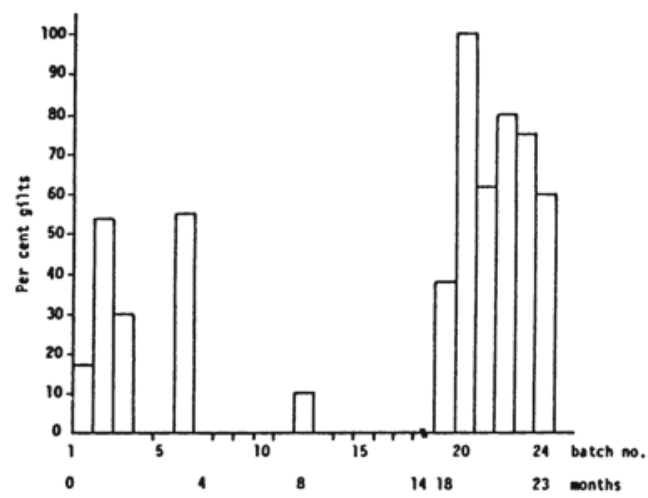

Figure 3. The percentage of gilts seroconverted to PPV at the time of 1 st vaccination in each of 24 batches comprising 326 gilts. Range of batch size 10 to 23 gilts. Vaccinations were carried out during a 23 months period.

values 32 to 64 and after the 2 nd vaccination to HI-titer values 128 to 512 . This level was largely unchanged at weaning time of the resulting 5 litters with a peak of the distribution curves at HI-titer values 128 to 512 (Fig. 5). During the trial period no increase of HI titer indicative of virus multiplication was observed except in a few animals after weaning of their 4th and 5th litters. No reproductive disturbances, however, related to infection with PPV occurred. The

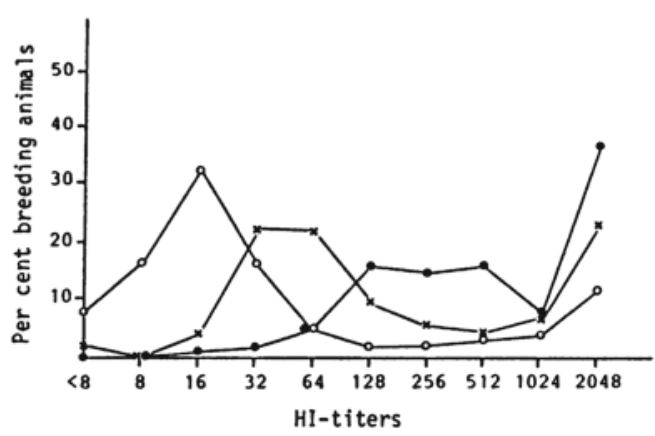

Figure 4. Antibody distribution in 326 breeding animals following vaccination with PPV vaccine. Samples taken at the time of the 1st vaccination $\mathrm{O}-\mathrm{O}$, at the time of the 2 nd vaccination $\mathrm{x}-\mathrm{x}$ and 3 weeks after the 2 nd vaccination 


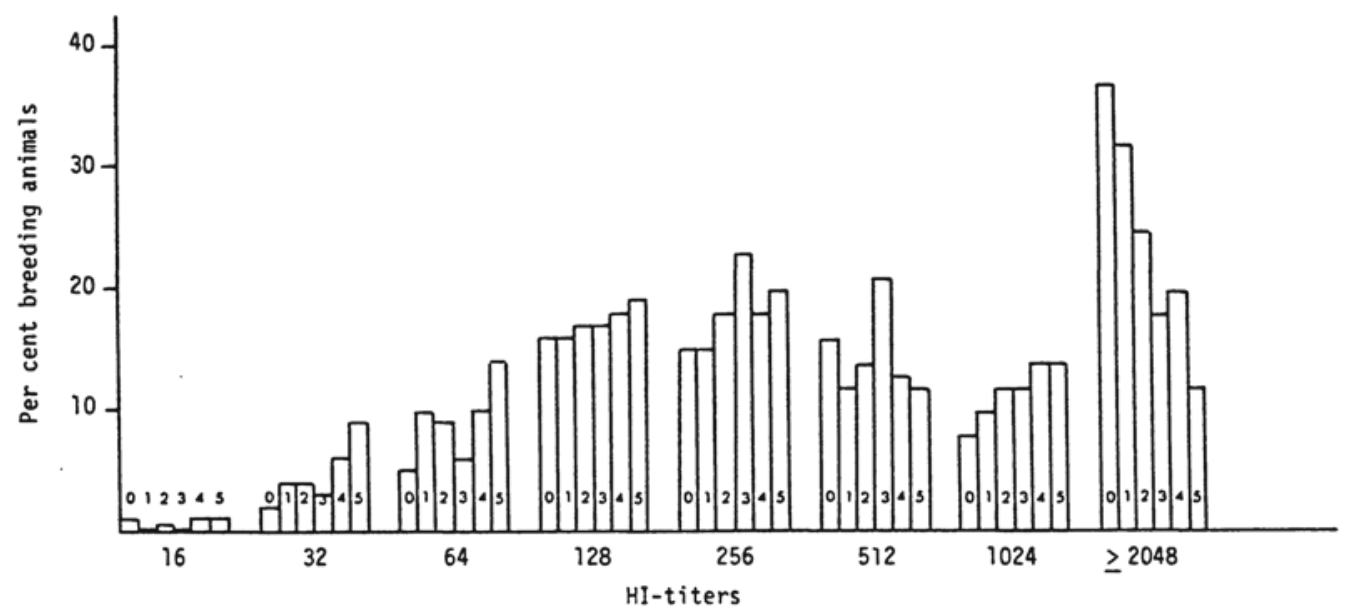

Figure 5. Long-term serostatus in a herd with continous vaccination of gilts before mating.

The columns represents blood samples collected: Column 0: Three weeks after 2 nd vaccination (326 animals), Column 1: At weaning time of the 1st litter (279 animals), Column 2: At weaning time of the 2 nd litter (225 animals), Column 3: At weaning time of the 3rd litter (179 animals), Column 4: At weaning time of the 4th litter (126 animals), Column 5: At weaning time of the 5th litter (86 animals).

Table 2. Antibodies to PPV before and after revaccination of 2 groups of sows with $1 \mathrm{ml}$ or $2 \mathrm{ml}$ of PPV vaccine preparation.

\begin{tabular}{lrrrrr}
\hline & \multicolumn{2}{c}{ HI titers, 1 ml vaccine } & & \multicolumn{2}{c}{ HI titers, 2 ml vaccine } \\
\cline { 2 - 3 } \cline { 5 - 6 } $\begin{array}{l}\text { Parity } \\
\text { no. }\end{array}$ & Before revac. & $\begin{array}{c}3 \text { weeks after } \\
\text { revac. }\end{array}$ & & Before revac. & $\begin{array}{c}3 \text { weeks after } \\
\text { revac. }\end{array}$ \\
\hline 1 & 32 & 512 & & 128 & 256 \\
2 & 16 & 128 & & 64 & 256 \\
3 & 256 & 2048 & & 32 & 512 \\
4 & 128 & 256 & & 128 & 256 \\
5 & 128 & 1024 & & 32 & 1024 \\
6 & 64 & 1024 & & 64 & 512 \\
\hline Mean value & 104 & 832 & & 75 & 469 \\
SD & 88 & 704 & & 44 & 299 \\
\hline
\end{tabular}

a 5 th and 6th litter sows vaccinated as gilts.

trial was terminated before the last 6 batches of animals had weaned their 4 th and 5th litters.

\section{Revaccination experiment}

In Table 2 the results obtained by revaccination of 2 batches of sows with relatively low titers to PPV with $1 \mathrm{ml}$ and $2 \mathrm{ml}$ of a
PPV vaccine preparation, respectively, are shown. Increased serum titers were seen in both batches.

\section{Discussion}

From the dose response experiments it could be concluded, that a single vaccination even with small amounts of inactivated virions in 
the vaccine elicited an antibody response to PPV in gilts without residual maternal serum antibodies. Under field conditions, however, a certain level of residual maternal serum antibodies is usually present at the time of vaccination. The dose response experiments demonstrated, that the presence of maternal serum antibodies had an inhibiting effect on the formation of HI-antibodies. Further, it was demonstrated, that a single vaccination even with a vaccine with high antigen content may fail to elicit a measurable antibody response, and that a double vaccination in such cases were needed to obtain an increase of antibody titer. In addition, it was shown that animals vaccinated with a vaccine with low antigen content may fail to develop a measurable antibody response even after a double vaccination. Under field conditions a double vaccination with the applied vaccine preparations gave a relatively high and long lasting antibody response, also when the gilts were vaccinated as early as at about 5 months of age.

In a field trial using 2 commercial vaccines de Leeuw et al. (1984) experienced, that after 1 injection of vaccine a considerable proportion of the animals remained seronegative. Some of these animals had no measurable maternal antibodies at the time of vaccination. Thacker et al. (1986) tested 6 commercial vaccines in a vaccination trial with seronegative gilts. Seroconversion was not observed in all gilts vaccinated according to the manufacturers recommendation (a single or a double vaccination at 2 weeks interval) with any of the 6 vaccines, and with 3 of them none of the gilts seroconverted. With 1 of the latter vaccines double vaccinations were performed.

To maintain the serostatus in older vaccinated animals revaccination later in life may be needed. In the present experiment, although it was carried out on relatively few animals, satisfactory results were obtained using either 1 or $2 \mathrm{ml}$ of the applied vaccine preparation for the revaccination. Under field conditions $2 \mathrm{ml}$ is recommended. The level of infection with PPV was reduced within about 4 months after the start of the vaccination trial as evaluated on the basis of the proportion of gilts, which had seroconverted at the time of the 1 st vaccination. After about 18 months a PPV infection occurred, which resulted in seroconversion in a high percentage of gilts before vaccination. Either the infection did not completely disappear, or it was possibly reintroduced. The infection apparently started in the fattening unit, from where the gilts were recruited. Thus, the infection seemed to occur in a younger group of pigs than before the start of the vaccination trial. This may be explained by a faster disappearence of maternal serum antibodies in offspring of vaccinated animals with lower HI titers to PPV, compared to the higher titer values induced by natural infection with PPV. Whether such feature is typical for herds, where a program with continuous vaccination of gilts before mating is applied, is not known at present. Further investigations are needed to elucidate the epidemiology of the infection in vaccinated herds.

\section{Acknowledgements}

We wish to thank Dr. O. Bro-Jørgensen, Jyderup, Mr. V. Pedersen and Mr. N. P. Willumsen, Astrup, Mr. F. Malmos, Kalundborg, Mr. H. T. Pedersen, Copenhagen, Mr. E. Bak, Tylstrup and Dr. N. C. Nielsen, Royal Veterinary and Agricultural University, Copenhagen, for discussions and/or technical assistance.

This work was supported by a grant from the Bergsøe Foundation. 


\section{References}

de Leeuw PW, Rouwette HJF, van Golstein $G W M$, Kuiper CJ: A comparison of two porcine parvovirus vaccines under field conditions. Proc. Int. Pig Vet. Soc. Congr., Ghent 1984, p. 14.

Edwards KR, Emmerson MA, Luff PR, Wells $D E$, Muskett JC, Wrathall AE, Richardson $C$, Parker BNJ, Thornton DH: Efficacy of porcine parvovirus vaccines. Vet. Rec. 1986, 119, 203-205.

Fujusaki $Y$, Watanabe $Y$, Kodama K, Hamada $H$, Murakami $Y$, Sugimori $T$, Sasahara J: Protection of swine with inactivated porcine parvovirus vaccine from fetal infection. Bull. nat. Inst. Anim. Hlth. 1978 a, 77, 9-11.

Fujisaki YT, Ichicara $T$, Sasaki $N$, Shimizu $F$, Murakami Y, Sugimori T, Sasahara J: Field trials on inactivated porcine parvovirus vaccine for the prevention of viral stillbirth among swine. Bull. nat. Inst. Anim. Hlth. 1978 b, 77, 12-14.

Joo HS, Molitor TW, Leman AD: Antibody responses of guinea-pigs, rabbits and pigs to inactivated porcine parvovirus vaccines. Vet. Microbiol. 1984, 9, 27-33.

Lei JC, Overby E, Holm Jensen M, Sørensen FO: Preparation of a porcine parvovirus vaccine. Proc. Int. Pig Vet. Soc. Congr., Copenhagen 1980, p. 64.

Mengeling WL, Brown TT, Paul PS, Gutekunst $D E$ : Efficacy of an inactivated virus vaccine for prevention of porcine parvovirus-induced reproductive failure. Amer. J. vet. Res. 1979, 40, 204-207.

Mengeling WL, Gutekunst DE, Pirtle EC, Paul $P S$ : Immunogenicity of bivalent vaccine for reproductive failure of swine induced by pseudorabies virus and porcine parvovirus. Amer. J. vet. Res. 1981, 42, 600-603.

Paul PS, Mengeling WL: Evaluation of a modified livevirus vaccine for the prevention of porcine parvovirus-induced reproductive disease in swine. Amer. J. vet. Res. 1980, 41, 2007-2011.
Paul PS, Mengeling WL: Vaccination of swine with an inactivated porcine parvovirus vaccine in the pressence of passive immunity. J. Amer. vet. med. Assoc. 1986, 188, 4, 410 415.

Plana J, Vayreda $M$, Pey $T$, Vila $X$, Marull $L$, Vilarrasa $J$ : Results of challenge in gilts vaccinated with a porcine parvovirus vaccine and with an associated vaccine against porcine parvovirus and aujeszky's disease. Proc. Int. Pig Vet. Soc. Congr., Ghent 1984, p. 11. Sørensen KJ, Askaa J: Vaccination against porcine parvovirus infection. Acta vet. scand. 1981, 22, 171-179.

Thacker BJ, Batista L, Gonzales RL, Saline R: Evaluation of commercial porcine parvovirus vaccines: Post-vaccination serological responses, hemagglutinating activity and long term serostatus of vaccinated gilts in an endemically infected herd. Proc. Int. Pig Vet. Soc. Congr., Barcelona 1986, p. 87.

Wrathall AE, Wells DE, Cartwright SF, Frerichs $G N$ : An inactivated, oil-emulsion vaccine for the prevention of porcine parvovirus-induced reproductive failure. Res. Vet. Sci. 1984, 36, 136-143.

\section{Sammendrag \\ Effektiv virkning af en inaktiveret porcin parvovirus (PPC) vaccine.}

Der præsenteres resultater af dosisrespons forsøg udført ved vaccination af grupper af seronegative sopolte og grupper af sopolte med maternelle antistoffer mod PPV. Der blev anvendt PPV vacciner med forskellig antigenindhold. Der blev foretaget 2 vaccinationer med 3 ugers mellemrum.

I seronegative dyr gav en enkelt vaccination et antistofsvar selv med vaccine med lavt antigenindhold. Titerværdierne steg efter anden vaccination. Hos dyr med maternelle antistoffer var antistofsvaret generelt lavere. I nogle tilfælde faldt titerværdierne efter første vaccination, men med undtagelse af 2 dyr vaccineret med vaccine med lavt antigenindhold fulgte en titerstigning efter anden vaccination. 
I et markforsøg i en besætning med enzootisk PPV infektion blev alle sopolte vaccineret med PPV vaccine før løbning. Der blev taget blodprøver før og efter vaccination og ved fravænning af de følgende 5 kuld. I alt blev 24 hold omfattende 326 dyr undersøgt. Det blev demonstreret, at vaccinen under de gældende forhold gav et relativt højt og langvarigt antistofsvar, selv når sopoltene blev vaccineret så tidligt som i 5 måneders alderen.

(Received September 11, 1987; accepted January 4, 1988).

Reprints may be requested from: K. J. Sørensen, State Veterinary Institute of Virus Research, Lindholm, DK-4771 Kalvehave, Denmark. 